\title{
自由曲げ振動に基づく遮熱コーティング層のヤング率の推定法†
}

\author{
荒 井 正 行* 岸 本 喜久雄**
}

\section{Estimation Method of Young's Modulus of Thermal Barrier Coating Layer Based on Free Bending Vibration}

by

\author{
Masayuki ArAI* and Kikuo KISHIMoto**
}

\begin{abstract}
A simple method for measuring Young's modulus of a coating layer is proposed based on a free bending vibration, and an experimental approach, by which a first-mode natural frequency of a flexuaral vibration produced by an impact of hammer is measured, is tried to estimate Young's modulus of the coating layer. The natural frequency equation with variable of the specimen geometries and Young's modulus is obtained by Timoshenko beam theory, and then Young's modulus of the coating layer is estimated by minimizing the objective function defined from the natural frequency equation. The proposed measuring method is applied to PMMA coating and thermal barrier coating. It is shown to be able to estimate the Young's modulus of both of coatings by the proposed method with good accuracy.
\end{abstract}

Key words : Young's modulus, Coating, Natural frequency, Free bending vibration, Timoshenko beam

\section{1 緒 言}

遮熱コーティングは，ガスタービン燃焼器や動・静翼 といった高温ガスに晒される部位の表面などに施される。 とくに，セラミックコーティングは，今までにも増して 厳しい環境下で使用できるよう，コーティング材料の開発 が活発に行われている状況にある.1)このため，コーティン グの物理的特性を十分に理解する必要がある。しかし， 一般にその特性はコーティングの施工方法に依存して， 例えば溶射法によって基材に堆積したコーティングの特 性と物理蒸着法によって堆積したそれとが大きく異なる ことが知られる。2)ここで，本研究では物理的特性として ヤング率に注目する。その主な理由は，ヤング率が材料 の変形抵抗を表わす重要な物理的特性であることによる.

これまでコーティングのヤング率は，コーティング層

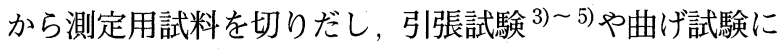
よって測定が行われてきた.6),7)信頼性がある従来の測定 方法に基づいてコーティングのヤング率を直接求めるこ とができる反面，測定用試料を採取するためにコーティ ング層を幅広く，かつ厚く堆積する必要が生じ，物理蒸 着法のように厚いコーティング層を堆積できない方法に は不向きである。 また，超音波法による測定方法 ${ }^{8)}$ も るが，測定の際に試料を水中にさらさなければならない. したがって，コーティング層が堆積された基材（以下， コーティング部材と呼ぶ）からコーティング層のヤング 率を簡単に測定できる方法の確立が望まれる。坂田ら ${ }^{9)}$ によって, チモシエンコのはり理論に基づいて, 鋼球を セラミックスの角柱形状の試料に自由落下させることで 生じた衝撃音から試料の固有振動数を求め, はりの固有
振動数の理論式からバルク材のヤング率を求めるという 優れた研究が行われている.

本研究では, 遮熱コーティング部材をボンドコーティ ング層を無視した 2 層はりとしてモデル化する．通常， ボンドコーティング層の厚さは数百ミクロンと薄く，ま たそのヤング率は基材の值に極めて近いためである。そ して, 坂田らの考え方に立脚して，2 層はりの自由曲げ 振動下での固有振動数を測定し，2 層はりの固有振動数 の理論式に基づいてコーティング層のヤング率を逆解析 的手法によって推定することを試みる。はじめに, 単体 のヤング率が知られているステンレス鋼基材と模擬コー ティング層としての PMMA 薄材とを接着した試料を用 い，ハンマにて試料に衝撃力を与えることで自由振動を 発生させるという簡単な実験を行い, 本手法の妥当性を 検証する。つぎに，Co 基超合金基材表面に部分安定化 ジルコニアコーティングを溶射した遮熱コーティング部 材を対象にコーティング層のヤング率を測定することを 試みる。

\section{2 理 論}

\section{$2 \cdot 1$ 自由曲げ振動下での 2 層はりの固有振動数}

Fig. 1 に本研究で対象としたコーティング部材を 2 層 はりにみたてたモデルを示す， 2 層はりの断面を, 高さ $h_{s}+h_{c}$, 幅 $b$ の長方形とし， はりの長さを $l$ とする. そ して，図に示す 2 層はりの下層をコーティング層，上層 を基材とし，コーティング層に関する諸量には下沿字 $c$ を，基材に関するそれには下沿字 $s$ をつけ。 この 2 層 はりのモデルに対して，はりの長手方向中央部の上面に 原点をとり，下向きに $y$, 右向きに $x$ となるように座標

$\dagger \quad$ 原稿受理 平成 14 年 6 月 24 日 Received June 24, 2002

* 正 会 員 電力中央研究所狛江研究所金属材料部 ₹201-8511 狛江市岩戸北, Material Sci. Dept., Central Res. Inst. of Electric Power Industry, Iwado-kita, Komae, 201-8511

** 正 会 員 東京工業大学大学院理工学研究科機械物理工学専攻 ₹152-8552 東京都目黒区大岡山, Dept. of Mech. and Cont. Eng., Tokyo Inst. of Tech., Meguro-ku, Tokyo, 152-8552 


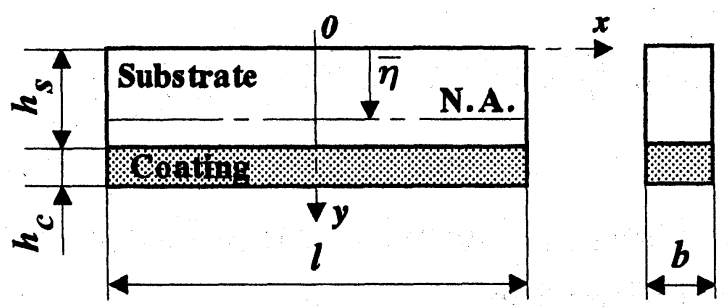

Fig. 1. Two layer beam model.

軸をとる。また，はり上面から $\bar{\eta}$ の距離に 2 層はりの中 立軸があるものとする。

この 2 層はりのたわみ $w(x, t)$ の運動方程式 ${ }^{10)}$ はつぎ のように表わされる。

$$
\frac{\partial^{2} w}{\partial t^{2}}+\frac{\overline{E I}}{\bar{\rho} \bar{A}} \frac{\partial^{4} w}{\partial x^{4}}=0
$$

ここで, $\overline{E I}$ は 2 層はり全体の等価曲げ剛さ, $E$ はヤン グ率, $I$ は断面 2 次モーメント, $\bar{\rho}$ は 2 層はり全体の密 度, $\bar{A}$ は 2 層はり全体の断面積をそれぞれ表わす。

2 層はりの両端に対して自由境界条件を課すことによっ て, 式 (1)からつぎの固有方程式を得る.

$$
1-\cosh (\lambda l) \cos (\lambda l)=0
$$

ここで, 固有方程式における第 1 次の根 $\lambda_{1}$, 第 2 次の根 $\lambda_{2}, \cdots$, 第 $i$ 次の根 $\lambda_{\mathrm{i}}$ は,

$$
\lambda_{i}=\frac{a i}{l}
$$

である.ここで，例えば第 1 次の根のときに相当した $a_{1}$ は 4.73 となる.

また, 第 $i$ 次の固有振動数と第 $i$ 次の根 $\lambda_{\mathrm{i}}$ との間には,

$$
\lambda_{i}^{4}=\frac{f_{i}^{2} \bar{\rho} \bar{A}}{\overline{E I}}
$$

の関係が成り立つ.

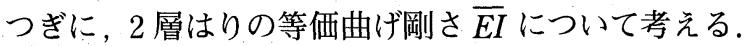
2 層はり上面からの中立軸の位置 $\bar{\eta}$ は,

より,

$$
\bar{\eta}=\frac{E_{s} \int y d A_{s}+E_{c} \int y d A_{c}}{E_{s} A_{s}+E_{c} A_{c}}
$$

$$
\bar{\eta}=\frac{E_{s} h_{s}^{2}+E_{c} h_{c}^{2}+2 E_{s} h_{s} h_{c}}{2\left(E_{s} h_{s}+E_{c} h_{c}\right)}
$$

となる.

等価曲げ剛さ $\overline{E I} は$,

$$
\overline{E I}=E_{s} \int_{A s}(y-\bar{\eta})^{2} d A s+E_{c} \int_{A c}(y-\bar{\eta})^{2} d A c
$$

であり，中立軸 $\bar{\eta}$ 考慮して積分を実行すれば，

$$
\begin{aligned}
\overline{E I} & =\frac{b}{3}\left[E_{s} h_{s}\left(h_{s}^{2}-3 h_{s} \bar{\eta}+3 \bar{\eta}^{2}\right)\right. \\
& \left.+E_{c} h_{c}\left(h_{c}^{2}+3\left(h_{s}-\bar{\eta}\right)^{2}+3 h_{c}\left(h_{s}-\bar{\eta}\right)\right)\right]
\end{aligned}
$$

を得る。

以上に示した式 (3)，(4)，(8)を用いることにより，コー ティング部材全体の固有振動数 $f$ を得る。なお，本研究 では後の議論を考慮して, 基材のみのときの固有振動数 $f_{0}$ でコーティング部材全体の固有振動数を無次元化した. この結果, 無次元化されたコーティング部材の固有振動 数 $\left(f / f_{0}\right)$ として

$$
\begin{aligned}
\left(\frac{f}{f_{0}}\right)^{2}=4\left[\left(1-3 \bar{\eta}^{*}\right.\right. & \left.+3 \bar{\eta}^{* 2}\right)+E^{*} h^{*}\left(h^{* 2}+3\left(1-\bar{\eta}^{*}\right)^{2}\right. \\
& \left.\left.+3 h^{*}\left(1-\bar{\eta}^{*}\right)\right)\right] \frac{1}{1+\bar{\rho}^{*} h^{*}}
\end{aligned}
$$

を得る。ここで, $f_{0}$ はコーティング部材からコーティン グ層をはがしたときの基材のみの固有振動数，基材によ って無次元化されたコーティング層厚さ $h^{*}=h_{c} / h_{s}$, な らびにはり上面からの中立軸の位置 $\bar{\eta}^{*}=\bar{\eta} / h_{s}$, 無次元 化されたコーティング層のヤング率 $E^{*}=E_{c} / E_{s}$, 無次元 化されたコーティング層の密度 $\rho^{*}=\rho_{c} / \rho_{s}$ をそれぞれ表 わす。 また，基材のみの固有振動数はつぎのように表さ れる.

$$
f_{0}^{2}=\frac{b}{12} E_{s} h_{s}^{3} a_{i}^{4} \frac{1}{m_{s} l^{3}}
$$

ここで， $m_{s}$ は基材の質量を表す. 以上のことから，コー ティング部材全体の固有振動数は, 試料の形状, 基材と コーティング層のヤング率, 試料の密度と関係付けられ ることがわかる.

\section{$2 \cdot 2$ 共役勾配法によるヤング率の推定法}

コーティング層のヤング率を推定する問題は, 式 (9) に基づいて, 無次元化ヤング率 $E^{*}$ を変数にみたてた以下 の目的関数 $A\left(E^{*}\right)$ を定義し，

$$
\begin{gathered}
A\left(E^{*}\right)=\mid\left(\frac{f}{f_{0}}\right)^{2}-4\left[\left(1-3 \bar{\eta}^{*}+3 \bar{\eta}^{* 2}\right)\right. \\
+E^{*} h^{*}\left(h^{* 2}+3\left(1-\bar{\eta}^{*}\right)^{2}\right. \\
\left.\left.+3 h^{*}\left(1-\bar{\eta}^{*}\right)\right)\right]\left.\frac{1}{1+\bar{\rho}^{*} h^{*}}\right|^{2}
\end{gathered}
$$

つぎの条件を満足するような変数 $E^{*}$ を探索することに帰 着される。

$$
A\left(E^{*}\right) \Rightarrow \min \text {. }
$$

なお，条件（12）となる最適な $E^{*}$ を探索するために，本 研究では共役勾配法 ${ }^{11)}$ を用いた。

\section{$2 \cdot 3$ 数值実験}

ここでは, 固有振動数式 (9)の関数形状について調べ る。はじめに，基材によって無次元化された密度 $\bar{\rho}$ ， 簡単のために 1.0 とおいたときの, 無次元化固有振動数の 二乗值 $\left(f / f_{0}\right)^{2}$ と無次元化ヤング率 $E^{\star}$ との関係を Fig. 2 に示す．無次元化ヤング率にともなって，つまり基材に 対してコーティング層のヤング率が大きくなるにつれて 無次元化固有振動数の二乗值は単調に増加することがわ かる.また，無次元化コーティング層厚さが増加，すな わち基材に対してコーティング層厚さが厚くなるにつれ て, 無次元化固有振動数の二乗值は増加していく傾向に ある。

Fig. 3 に無次元化コーティング層厚さに伴う無次元化固 有振動数の二乗值の変化を示す. 無次元化コーティング 層厚さとともに無次元化固有振動数の二乗值は高くなっ ていく．また，無次元化ヤング率が大きくなると無次元 化固有振動数の二乗值は急速に増加していくこともわ かる. 以上のことから, 無次元化ヤング率および無次元化 コーティング層厚さに対して, 無次元化固有振動数の二 乗值は単調に変化することがわかり，このことは目的関 


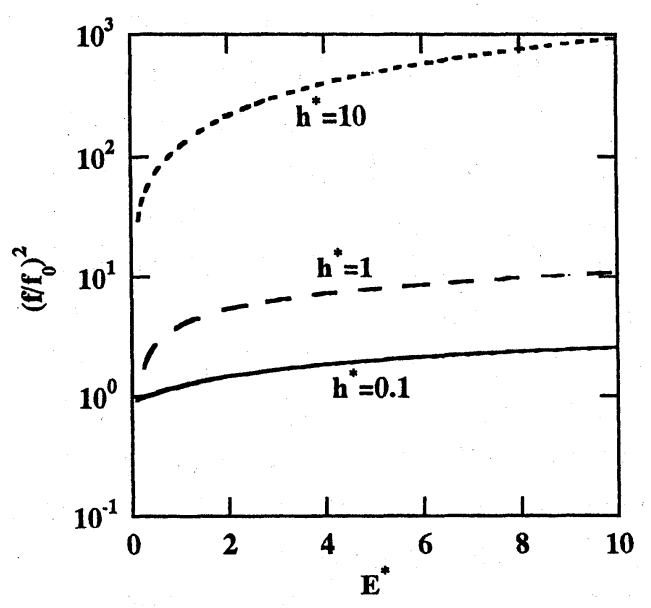

Fig. 2. Variation of normalized natural frequency $\left(f / f_{0}\right)^{2}$ with normalized Young's modulus.

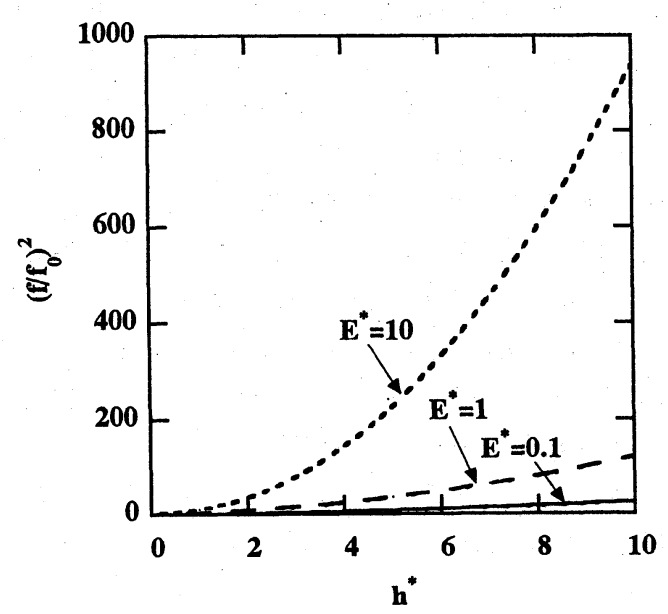

Fig. 3. Variation of normalized natural frequency $\left(f / f_{0}\right)^{2}$ with normalized beam thickness.

数 $A\left(E^{*}\right)$ が最小となる唯一つの $E^{*}$ が存在することを保 証する.

つぎに, 目的関数式 (11) を最小化する变数 $E^{*}$ を数値 的に求めることを試みた。 Fig. 4 に，真值のヤング率 $E_{\text {true }}^{*}$ と推定されたヤング率 $E_{\text {est }}^{*}$ との間の誤差について調 ベた結果を示す。ここに示す結果は, 求めたい無次元化 ヤング率 $E_{\text {true }}^{*}$ として 0.7 を仮定し, また無次元化密度 $\rho$ を 1.0 とし, 無次元化コーティング層厚さ $h^{*}$ を種々変化

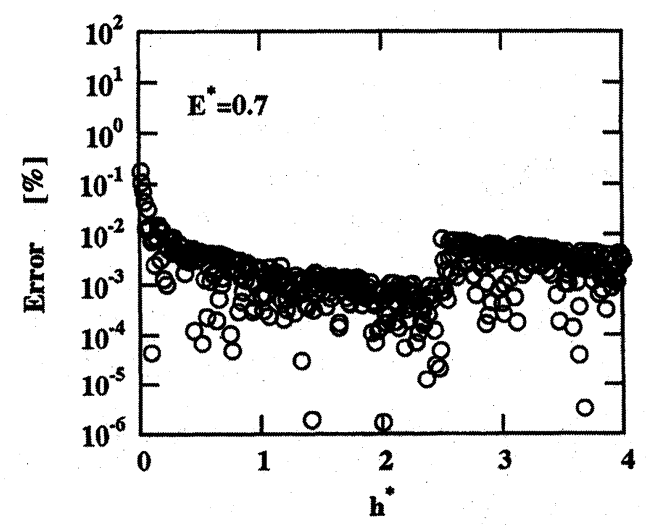

Fig. 4. Estimation error of Young's modulus.
させたことによって得たものである.実際の数値計算に おいては，あらかじめ仮定しておいた無次元化ヤング率 を式 (9)に代入することで無次元化固有振動数 $\left(f / f_{0}\right)$ を 求め, この固有振動数と測定試料の密度と形状が与えら れているものと考え，共役勾配法によって目的関数式 (11)を最小にする $E^{*}$ を求めた。ここで, 推定誤差はつぎ の式によって定義した。

$$
\text { Error }=\left|\frac{E_{\text {true }}^{*}-E_{\text {est }}^{*}}{E_{\text {true }}^{*}}\right|
$$

推定誤差について調べた結果, 無次元化コーティング 層厚さ $h^{*}$ が小さい，すなわちコーティング層厚さが基材 に比べて薄い場合には, 推定誤差 $0.1 \%$ 程度となるもの の，本手法を用いることによってコーティング層厚さに ほとんど依存せずにコーティング層のヤング率を推定で きることが確認できた。

$$
3 \text { 実験 }
$$

\section{$3 \cdot 1$ 実験装置および実験手順}

実験装置と計測システムの概要を Fig. 5 に示す。図に 示すように支柱上端に測定用試料の両端を水平にひもで つるす。そして，ハンマによってかるく試料中央部，基 材表面側を吒く，吅いた面の近傍にはひずみゲージがあら かじめ付着してあり，ひずみゲージからの出力をブリッジ ボックスを介してストレインアンプに入力し，ハンマに よる衝撃後の時間に伴うひずみの変化をX-Yレコーダに て記録する．また，ストレインアンプからの信号をシグ ナルアナライザ（岩崎通信機製，SM-2100C）へも入力 し，ひずみ一時間応答に対する周波数解析を行う。この 解析結果に基づいて, ピークの鋭い点から 1 次, 2 次の 固有振動数を求める.

\section{$3 \cdot 2$ ヤング率の推定手順}

コーティング層のヤング率の推定手順について説明する.

(1) 測定試料の重量, 形状を測定する.

（2）基材のヤング率がわかっている場合には，式 (10) に代入して基材のみの固有振動数 $f_{0}$ を求める. わかって いない場合には，基材のみの試料をハンマで吅くことに より基材の固有振動数を直接求める。 そして, 式 (10)に 直接測定することで得た固有振動数を代入して基材のヤ ング率を求める.

（3）測定試料をハンマで吒き，ひずみ一時間応答を周 波数解析することで, 固有振動数を測定する.

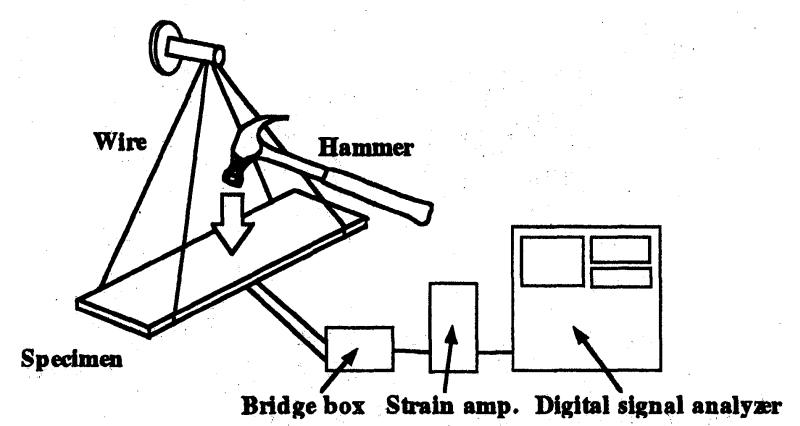

Fig. 5. Experimental system. 
(4) 目的関数式 (11) 中に, 以上により得られた諸量 を代入し，共役勾配法によって目的関数を最小にする $E^{*}$ を求める。

(5) 無次元化ヤング率 $E^{*}$ に基材のヤング率 $E_{s}$ を乗じ ることによってコーティング層のヤング率 $E_{c}$ を得る.

\section{$3 \cdot 3$ 測定および推定結果}

本節では，はじめに単体のヤング率がわかっている SUS 304 鋼平板を基材とし, コーティング層として PMMA と した試料を用いて, 本研究で提案する手法の妥当性を検 証する。つぎに，基材がコバルト基超合金 HA188 平板， トップコーティング層が 8 mass $\% \mathrm{Y}_{2} \mathrm{O}_{3}-\mathrm{ZrO}_{2}$ （以下， $8 \mathrm{YZ}$ と呼ぶ.）の遮熱コーティング部材を対象に，コーティン グ層のヤング率推定を試みる。前者は, エポキシ樹脂系 接着剤を基材上に薄く塗り，その上にコーティング層と しての PMMA 平板をのせて接着させ, 約 2 日間放置し た後に測定用試料に供した. 後者は, コバルト基超合金 平板上に大気プラズマ溶射装置によってボンドコーティ ング層としての CoNiCrAlY 合金を $0.1 \mathrm{~mm}$ 堆積させ，そ の上にコーティング層を堆積させ，これを測定用試料に供 した. 測定用試料の形状を Table I にまとめて示す.こ こで, 表中のヤング率は, それぞれの層から測定用試料 を切り出し, 曲げ試験によって別途測定した結果である.

ハンマ衝撃後に得られたひずみ一時間応答の測定結果 の代表例として, Fig. 6 にSUS304 + PMMA 試料の結果

Table I . Specimen geometries.

\begin{tabular}{ccccc}
\hline & SUS304 & PMMA & HA188 & 8YZ \\
\hline I[mm] & 100 & 100 & 63.7 & 63.7 \\
b[mm $]$ & 20 & 20 & 21.7 & 21.7 \\
h[mm $]$ & 1.0 & 1.0 & 2.12 & 1.0 \\
$\mathrm{~m}[\mathrm{~g}]$ & 16.0 & 1.0 & 24.7 & 7.8 \\
$\rho\left[\mathrm{kg} / \mathrm{m}^{3}\right]$ & 8010 & 490 & 8430 & 5640 \\
E[GPa $]$ & 206.0 & 1.6 & 231.0 & 41.0 \\
\hline
\end{tabular}

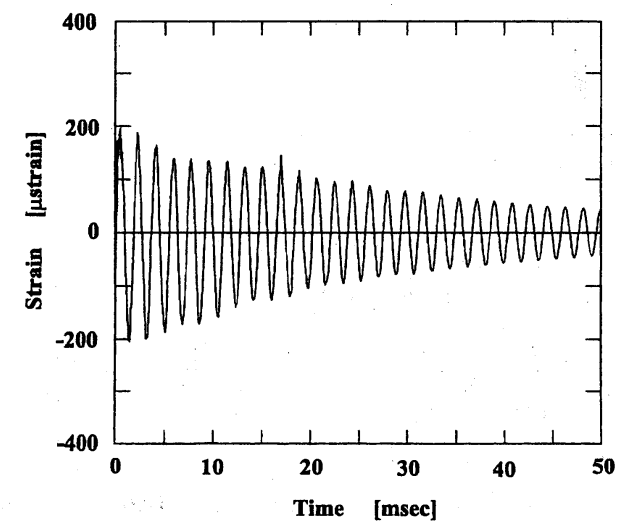

Fig. 6. Strain responce of SUS304+PMMA specimen.
を示す，図より，ハンマにて試料表面を吒いた直後に発 生したひずみは, 時間とともに急速に減衰していく様子 がわかる。なお，ハンマにて与えた衝撃力の違いによっ てはじめのひずみ量は異なってくるが，いずれのひずみ 応答においてもひずみの急速な減衰が認められた。

このひずみ一時間応答に対して周波数解析したことで 得た 1 次固有振動数は $f_{1}=540 \mathrm{~Hz}$ であった. なお，同一 試料に対して 3 回測定を行ったが, 衝撃力の違いにかか わらずそれらの固有振動数の值はほとんど同じであり， ばらつきは $1 \%$ 未満であった. また, 1 次〜 3 次までの固 有振動数を求めることができたが，ヤング率の推定にあ たっては 1 次固有振動数のみを用いた。

つぎに，ハンマーによる衝撃によって測定された 1 次 固有振動数に基づいて, PMMA + SUS304 コーティング 部材のヤング率を推定した結果, PMMA コーティング材 のヤング率 $E_{c}$ は $1.65 \mathrm{GPa}$ であった. PMMA 単体のヤン グ率は $1.60 \mathrm{GPa}$ であることがわかっているので, 推定さ れたヤング率は数パーセントの誤差が認められたものの， 既知のヤング率值とよく一致していることが確認された。

つぎに遮熱コーティング部材について実験を行った。 ハンマーによる衝撃によって得られた 1 次固有振動数は $2880 \mathrm{~Hz}$ であった。 これにより推定されるコーティング層 のヤング率は, $E_{c}=39.3 \mathrm{GPa}$ となった. コーティング層 から切り出した試料を別途曲げ試験することで得られる ヤング率が $41 \mathrm{GPa}$ なので, 両者はほぼ一致しており，本 手法により遮熱コーティング部のコーティング層のヤン グ率推定が可能であることが確かめられた。

ところで, 本試験においていずれの材料に打いても生 じた誤差の原因は, 測定用試料をつるすひもの弾性変形 に起因したものと考えられる。本実験で用いたひもは， たこ糸なので，より剛性が高いひもを用いることによっ て推定精度はより向上するものと考えられる。また，い ずれの材料においてもボンド層の存在が 2 層モデルに基 づくコーティング層のヤング率の推定結果に与える影響 は少なかった。これは界面での密着性が高かったこと， ボンド層厚さが $0.1 \mathrm{~mm}$ と, 基材, コーティング層厚さに 比べて薄く，この層の影響が無視できることに起因した ものと考えられる. ただし, 施工方法, ボンドコーティ ング材の種類によってはやわらかい特性のものもあるの で, この点についても今後検討する余地があるものと考 える.さらに本研究では, ひとつの試料形状, ある限ら れたコーティング層と基材との組み合わせを対象とした が, 試料形状が測定結果に及ぼす影響, 他の材料系への 手法の適用などいくつかの課題も残されている.

\section{4 結 言}

本研究では, 遮熱コーティング部材を 2 層はりとみな して，2 層はりが自由曲げ振動する際の固有振動数に注 目し, コーティング部材全体の固有振動数からコーティ ング層のヤング率を逆解析的に推定する方法を示した。 はじめにヤング率が既知のステンレス鋼基材上に貼り付 けられた PMMA コーティング部材を用いて本手法の妥 当性を確認した。つぎに，コバルト基超合金基材上に大 
気溶射法によって施工されたセラミックス遮熱コーティ ングのヤング率を推定することを試みた。 今後は, 本モ デルを 3 層はりモデルに拡張し , トップコーティングと ボンドコーティングの両者を推定しうる手法の開発を試 みる予定である. な招, 本研究の実施にあたっては, 当 時東京工業大学学部生鹿島寛士君の協力を得た.

\section{参 考 文 献}

1) Committe on Coatings for High-Temperature Structural Materials, "Coatings for High - Temperature Structural Materials-Trends and Opportunities -", p.22 (1996) National Academy Press.

2) 井上泰宣, 鎌田喜一郎, 浜崎勝義訳, ” 薄膜物性入門”, p.228（1998）内田老鶴围.

3 ) T. A. Cruse, S. E. Stewart and M. Ortiz, Journal of Engineering for Gas Turbines and Power, 110, 610 (1988).

4) R. C. Novak, Journal of Engineering for Gas Turbines and Power, 110, 617 (1988).

5 ) R. C. Brink, Journal of Engineering for Gas Turbines and Power, 111, 570 (1989).

$6 ）$ 伊藤義康, 機械の研究，47，947（1995）

7 ) 荒井正行, 佐久間俊雄, 水谷明史, 岸本喜久雄, 斎藤正 弘, Journal of the Ceramics Society of Japan, 106, 198 (1998).

8）たとえば川島紜一郎，非破壊検査， 51，397（2002）.

9) 坂田 勝, 木村康治; 水沼明子, 下条 純, 日本機械学 会論文集，A-58，2359（1992）。

10）西村源六郎, “振動工学”, p.343（1969）誠文堂新光社.

11）大野 “豊, 磯田勝男監修, “数値計算ハンドブック”, p.791（1990）オーム社. 